\title{
Transtensional Tectonics Played a Key Role during the Variscan Cycle in the Sardinia-Corsica Massif
}

\author{
Nello Minzoni \\ Dipartimento di Scienze della Terra; Università di Ferrara
}

Italy

\section{Introduction}

Analysis, interpretation and synthesis of the Variscan (Hercynian) chain in the whole Sardinian-Corsican Massif (SCM) are relatively recent. Previous studies were carried out only in SW Sardinia, characterized by important ore deposits and abundant fossils.

Afterward, in SE Sardinia (Sarrabus region) Calvino, 1961, recognized terrigenous deposits ("San Vito" Fm.) and intrusive magmatics ("Porfidi bianchi" and "Porfidi grigi"), assigned to a generic early Paleozoic.

Bosellini \& Ogniben, 1968, discovered, in central Sardinia (Sarcidano region) volcanoclastics ("Manixeddu" Fm), volcanics ("Serra Tonnai” Fm), middle Ordovician in age and a thick terrigenous turbiditic succession ("Bruncu su Pizzu" Fm) late Ordovician in age

Minzoni, 1975, identified, in the Sarcidano and Barbagia regions (central-northern Sardinia) a terrigenous succession ("Solanas “Fm), middle Cambrian -early Ordovician in age, covered by sub-aerial acidic volcanics ("Monte Corte Cerbos "Fm.), middle Ordovician in age, in turn covered by the Manixeddu volcanoclastics and by Serra Tonnai volcanics and Bruncu su Pizzu turbidites.. The Solanas Fm was considered equivalent to the San Vito Fm and the effusive Monte Corte Cerbos and Serra Tonnai volcanics were considered equivalent to the intrusive Porfidi bianchi and Porfidi grigi.

Structural analysis indicated that from late Devonian to early Carboniferous the Variscan orogenesis piled up, in central-northern Sardinia, several south- vergent nappes. North Sardinia was considered the internal zone of the chain, source of the nappes, that were stacked in central-northern Sardinia (Nappe zone) and transported toward southern Sardinia (external chain and foreland).

The Variscan geodynamic cycle was considered completely ensialic, involving continental crust only. North Sardinia was assumed as the portion of the crust most deeply subducted along an intra-continental shear zone and North Corsica was regarded as backland of the chain (Carmignani et al., 1980; 1981).

Afterward, Carmignani et al., 1992, discovered, in northern Sardinia, along a narrow belt (the "Asinara -Posada Line"), small mafic bodies of amphibolite, bearing granulite-eclogite relics. Geochemical data indicated a MORB affinity for the protolith and radiometric dating (Sm / Nd on whole rock; Cappelli et al., 1992), yielded an age of $960 \pm 93$ Ma. The granuliteeclogite relics were related to subduction processes of oceanic lithosphere, retrogressed in 
the amphibolite facies during the Variscan metamorphism. Using these data, this model was proposed: opening in North Sardinia of an ocean during the pre Cambrian.; subduction, during the middle Ordovician, of the oceanic lithosphere and development, in central Sardinia, of a volcanic arc on continental crust; further subduction, during the Silurian, of the oceanic lithosphere; continental collision of the paleo margins in north Sardinia during late Devonian-early Carboniferous and oceanic suture ("Asinara -Posada Line"); gravitative collapse of the thickened orogenic wedge, with ascent of the deepest metamorphic cores; crustal extension and emplacement of granitoids.

Rossi et al., 2009 proposed this geodynamic cycle: Cambrian -Early Ordovician, opening of the Rheic Ocean in central Europe; Middle Ordovician, subduction of the Rheic Ocean and development of an Andean-type volcanism in Sardinia; Late Ordovician -Early Silurian, back arc spreading and rifting on the North Sardinia-central Corsica and opening of the "South Armorica Ocean"; Silurian -Devonian, subduction of the Armorican Ocean; Late Devonian - early Carboniferous, collision of the passive margins; Carboniferous-Early Permian, extension and emplacement of the batholith.

In both the models, the middle Ordovician magmatics in Sardinia represent an arc generated by subduction of oceanic lithosphere.

\section{Aim of this chapter}

Aim is to propose, reviewing the Paleozoic events in the SCM, a new geodynamic model, in the frame of the European Variscan Realm.

\section{The Variscan cycle in the Sardinia - Corsica Massif: data and interpretation}

Figure 1 represents the main features of the Variscan chain in the SCM.

\subsection{Foreland}

Data. SW Sardinia is the external zone and the foreland of the Variscan chain. Near Capo Spartivento, a metamorphic complex ("Settiballas complex", Minzoni, 1981) is cut and metamorphosed by contact by a granitoid (" Orthogneis " or "Porphyroid", in literature). These rocks are covered by the "Bithia Fm.", consisting in arkoses, quarzites, conglomerates, shales and siltites, with thin dolomitic intercalations. Few badly preserved Acritarchs have been assigned to the early Cambrian.

The Bithia Fm grades into early-middle Cambrian terrigenous deposits, with Archeocyat and Trilobite-bearing carbonate levels ("Nebida Fm.").

The middle Cambrian is represented by a thick carbonate succession ("Gonnesa Fm.").

The early-middle Cambrian deposits reach a thickness of about $2000 \mathrm{~m}$.

The deposition in shallow marine conditions of a siliciclastic succession ("Cabitza Fm."), showing a thickness of about $400 \mathrm{~m}$, characterizes the late Cambrian-early Ordovician (Barca et al., 1987).

SW Sardinia, experienced a mild tectonic phase that developed E-W directed folds ("Sardic" Phase).

A conglomerate ("Puddinga") represents the middle-late Ordovician transgression, after a short-lived emergence and erosion (Martini et al., 1991). This conglomerate grades upward into a thin (50-100 m) succession constituted by siltites and marly shales, late Ordovician in age (“Tuviois” Fm). 


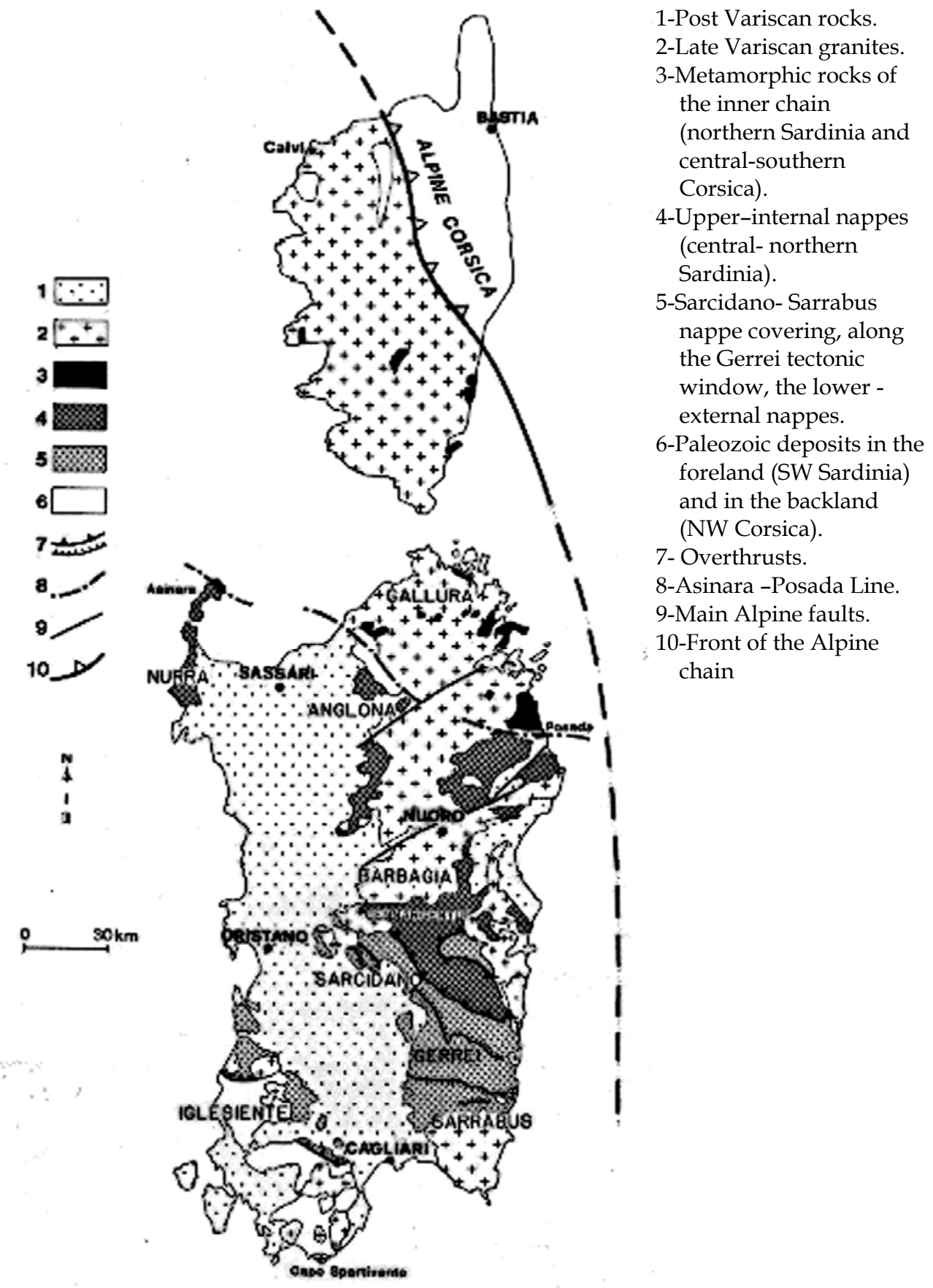

Fig. 1. 
The Silurian and the Devonian are represented by the well known pelagic black shales and Tentaculite-bearing limestones.

The main Variscan tectonic phase generated N-S directed folds which, interfering with E-W folds of the Sardic phase, formed a "dome-basin" structural setting. Downward, the Variscan folds become progressively recumbent- isoclinal in type, characterized by subhorizontal pervasive cleavage and by syn tectonic matamorphism increasing downward from the Anchizone to the green-schist facies. The Variscan cleavage cuts the schistosity of the Settiballas metamorphic complex; the granitoid was transformed in the Orthogneiss Porphyroid.

Interpretation. The Settiballas metamorphic complex and the granitoid (OrthogneissPorphyroid), both represent a pre-Cambrian (pan -African) Basement. It is generally accepted (Cocozza, 1980; Vai \& Cocozza, 1986; Gandin, 1987; Gandin et al., 1987; ) that the overlying deposits formed in epi-continental domain, evolving from a delta oolitic lagoonal-tidal flat system to open marine conditions. Their thickness $(2400 \mathrm{~m})$ suggests that the sedimentation was linked to slow subsidence controlled by long-lived syn-sedimentary normal faults.

The Sardic Phase formed structures locally emerging from a shallow sea. The emergence is pre-dated by the Arenig deposits at the top of the Cabitza Fm and post-dated by the Caradocian deposits of the Tuviois Fm (Vai \& Cocozza, 1986) This last consists in fluviolacustrine-shallow marine sequences, formed after short-lived emergence.

The Silurian-Devonian succession is usually considered the result of a worldwide climatic transgression (Vai, 2001).

\subsection{Nappe zone}

In central-northern Sardinia, the main Variscan orogenetic phase piled up several southward- verging nappes (Nappe Zone) characterized by isoclinal- recumbent folds, pervasive slaty cleavage and by northward increasing ( from greenschist-to- amphibolite facies) metamorphism.

NE Sardinia represents, in this way, internal zone of the Variscan chain, source of the nappes which were piled up in northern-central Sardinia and transported toward SW (external chain and foreland).

In this frame, the lower nappes represent external domains adjacent to SW Sardinia (lowerexternal nappes) and the upper nappes represent internal domains adjacent to NE Sardinia (upper-internal nappes).

The Sarcidano-Sarrabus tectonic unit, sandwiched between the lower and the upper nappes, represents an area linking the external with the internal domains.

\subsubsection{Lower-external nappes}

Data. These small-sized nappes outcrop in the "Gerrei window", beneath the SarcidanoSarrabus tectonic unit (Fig.1). They consist of the pre Cambrian Orthogneiss-Porphyroid covered by arkoses $(10-50 \mathrm{~m})$, siliciclastic sequences $(30-80 \mathrm{~m})$ middle Cambrian -early Ordovician in age (Cuili Biringoni Fm), siltites and limestones (10-60 m) CaradocianAshgillian in age (Tuviois Fm) and black shales -limestones (80-100 m) Silurian-Devonian in age.

Interpretation. The non deposition on the pre Cambrian Basement of the early-middle Cambrian successions indicates that until the middle Cambrian the lower nappes constituted a terrestrial area extended North of SW Sardinia, this last being affected by the syn sedimentary normal faults controlling the deposition of the Bithia- Nebida-Gonnesa Fms. 
The terrestrial condition was interrupted from late Cambrian with the deposition of the Cuili Biringoni Fm. This corresponds, in age but not in thickness, to the Cabitza Fm in SW Sardinia. Therefore, the lower nappes constituted, during the late Cambrian-early Ordovician, an Horst (characterized by the deposition of the condensed Cuili Biringoni Fm) adjacent to a Graben in SW Sardinia (characterized by the deposition of the thick Cabitza Fm).

Instead, during the late Ordovician the sedimentation developed homogeneously in the SW Sardinia and in the area of the lower nappes, being represented, everywhere, by the Tuviois Fm.

\subsubsection{Sarcidano-Sarrabus nappe}

Data This enormous tectonic unit extends from the Sarcidano -Sarrabus to the Iglesiente ( Barca et al., 1984; Albani et al., 1985) thus covering all the lower external nappes and reaching the external zone of the chain. This unit starts with the late Cambrian-early Ordovician San Vito-Solanas Fms showing a thickness of about $400 \mathrm{~m}$. Both correspond, in thickness and in age, to the Cabitza Fm in SW Sardinia.

Emplacement of felsic calc-alkaline -to-basic alkaline magmatics ("Porfidi bianchi" "Porfidi grigi" and Monte Corte Cerbos-Serra Tonnai volcanics) characterizes the middlelate Ordovician. (Fig.2)

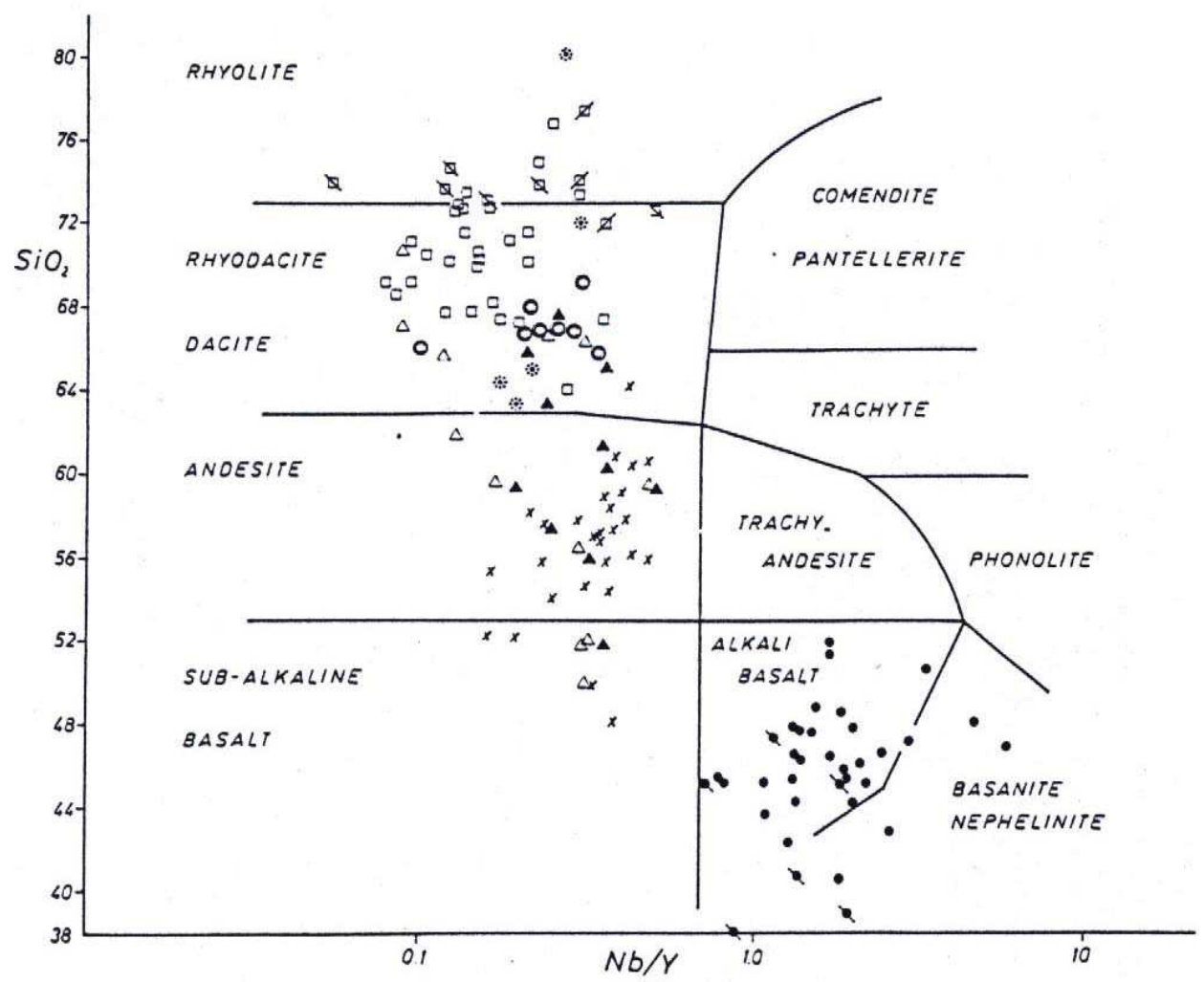

Fig. 2. Middle-to- late Ordovician magmatics in central-northern Sardinia 
The erosion of the Monte Corte Cerbos volcanic edificies caused the deposition of the Manixeddu volcanoclastics. Until the early Ordovician the sedimentation developed in similar conditions in the Sarcidano and in the Sarrabus with the deposition of the San Vito and Solanas Fms. The conditions changed during the late Ordovician, with deposition of the thin -condensed Tuviois Fm in Sarrabus and of the thick-turbiditic Bruncu su Pizzu Fm in Sarcidano The Silurian and Devonian consist, in the whole nappe of the black shale ad carbonate sediments.

Interpretation. The thickness $(400 \mathrm{~m})$ of the San Vito- Solanas Fms indicates that the Sarrabus and Sarcidano constituted, from late Cambrian to early Ordovician, a Graben controlled by syn sedimentary normal faults. Therefore, the area of the lower nappes, characterized by the thin-condensed Cuili Biringoni Fm, constituted an Horst between the two Grabens, in SW Sardinia and in the Sarrabus-Sarcidano areas.

During the emplacement of the nappe, the syn sedimentary normal faults were inverted and transformed in thrust surfaces, covering the Horst which was dismembered in the small lower nappes.

The emplacement in central-northern Sardinia of abundant magmatics argues in favor of the development during the middle Ordovician of an intra continental rifting, controlled by extensional tectonics. On the other hand, these tectonics developed at the same time of the compressional tectonics in SW Sardinia ("Sardic phase"). Such heterogeneous distribution of the deformation and its spatial variation indicate that during the middle Ordovician, the SCM was affected by wrench dynamics, causing contemporaneously transpressional and transtensional phenomena.

\subsubsection{Upper internal nappes}

Data. These nappes occur in central-northern Sardinia (Fig.1). In the Gennargentu, the late Ordovician Bruncu su PIzzu Fm reaches a thickness of about 1000 m (Dessau et al., 1982). Isoclinal recumbent folds, well-developed metamorphic cleavage and strong stretching lineations characterize these nappes.

Interpretation. The northward increasing thickness of the late Ordovician turbiditic sequences indicates that only from the late Ordovician an internal domain, extended in central -northern Sardinia (from the Sarcidano to the Gennargentu to the northern Sardinia; that is the areas characterized by the sedimentation of the turbiditic Bruncu su Pizzu Fm) was opposed to an external domain, extended in central-southern Sardinia (from SW Sardinia to the lower external nappes to the Sarrabus; that is the areas characterized by the deposition of the epicontinental Tuviois Fm ). Therefore, in the strict sense only from the late Ordovician the true Variscan cycle began to develop.

\subsection{Asinara-Posada line}

Data. The Asinara-Posada Line (APL) in NE Sardinia, is a km-sized belt in the amphibolite facies, characterized by occurrence of small bodies of amphibolites, containing granulitic or eclogitic relics (Ghezzo et al., 1980), representing remnanys of oceanic crust, trapped between two collided passive margins.

Interpretation. The transtensional tectonics that developed during the late Ordovician with increasing intensity toward NE, reached their acme along the APL, thus opening of an oceanic basin. 


\subsection{Innermost chain}

The part of the Variscan chain from the APL to the central Corsica consists (Rossi et al., 2009, references therein) of intermediate pressure amphibolite facies, migmatite and migmatitic gneisses.

This part of the chain represents the innermost area of the Variscan belt.

\subsection{Backland}

Data. The backland of the chain outcrops in northern Corsica.

In NW Corsica, a metamorphic complex ("Argentella complex") is covered by a Paleozoic succession. This starts (Baudelot et al., 1977) with thin terrigenous deposits, late Cambrianearly Ordovician in age, affected by a mild compressional phase during the middle Ordovician. The transgression is documented by a conglomerate followed by a thin terrigenous formation late Ordovician in age, covered by the Silurian-Devonian sediments. The Carboniferous consists of carbonate levels ("Calcaire de Capitello").

Interpretation. The Argentella complex represents the pre Cambrian Pan African Basement. The non deposition of the early-middle Cambrian sediments indicates that NW Corsica rconstituted, during this interval of time, a terrestrial area.

The overlying transgressive siliciclastic sequences, late Cambrian-early Ordovician in age, correspond, in thickness and in age, to the Cuili Biringoni Fm in Sardinia; this is in favor of the Horst-Graben structural setting during late Cambriam-early Ordovician times..

The compressional middle Ordivician tectonics indicate that the Sardic Phase also affected NW Corsica. The conglomerate at the base of the late Ordovician succession corresponds to the "Puddinga" in SW Sardinia.

The late Ordovician sequences correspond to the Tuviois Fm in central-southern Sardinia. Therefore, central-southern Sardinia and northern Corsica (both characterized by epicontinental deposits) constituted the external areas opposed to the internal zone in north Sardinia-central Corsica, ( characterized by the turbiditic deposits and overall by the ophiolite-bearing successions).

\section{Discussion}

The various events that, starting from the early Cambrian, progressively affected the SCM, offer a great deal of information about the development of the Variscan geodynamic cycle in this southern segment of the European Variscan Realm. Different thickness of the sediments, their lateral and vertical changes, variations in deposition rate, break in sedimentation, angular unconformities and magmatism: all of them record changes in crustal dynamics and allow to trace the space-time evolution of the orogenetic belt.

Figure 3, summarizes the most representative events.

The sedimentation began from the early Cambrian covering a pre-Cambrian (Pan-African) Basement, represented by metamorphics and by a granite ("Othogneiss"- "-Porphyroid"). Radiometric datings yielded for these last a middle Ordovician age. However, the overlying arkoses interbedded with the early Cambrian deposits are in favor of a pre Cambrian age. Therefore, the granite represents a magmatism concluding a pre-Cambrian orogenetic cycle. The early -middle Cambrian sediments (Bithia, Nebida and Gonnesa Fms) were deposited only in SW Sardinia. Syn sedimentary long-lived extensional tectonics controlled their thickness. 


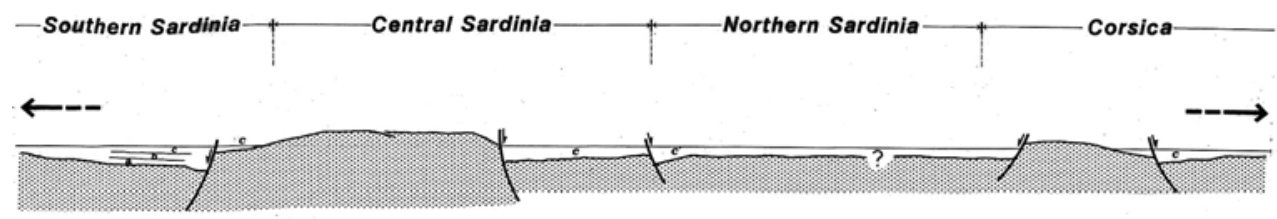

Early Cambrian-Early Ordovician
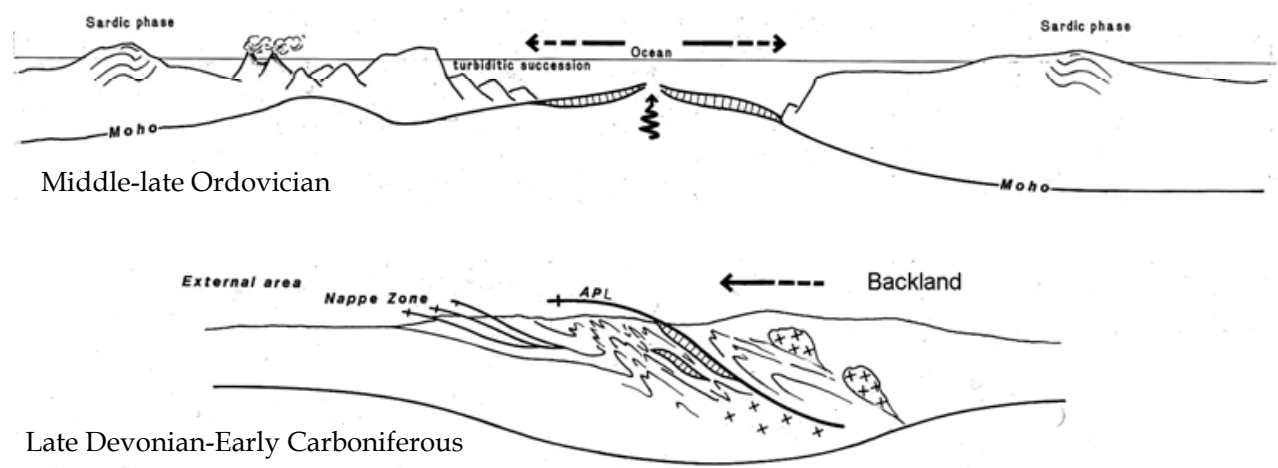

Fig. 3. Variscan geodynamic cycle in the Sardinia-Corsica Massif.

Early-middle Cambrian: sedimentation, in SW Sardinia, of a) Bithia and Nebida Fms.

b) Gonnesa Fm.

Late Cambrian- early Ordovician: deposition in the whole Sardinia-Corsica Massif of c)

Cabitza- San Vito -Solanas - Cuili Biringoni Fms.

Middle Ordovician: Transpressional and transtensional tectonics, development of "Sardic Phase" and emplacement of felsic calc alkaline magmatics.

Late Ordovician: deposition, of a thick turbiditic succession (Bruncu su Pizzu Fm) and emplacement of basic alkaline magmatics.

Late Ordovician -Silurian: opening the Asinara-Posada Ocean

Late Devonian-early Carboniferous. Orogenesis and formation of the chain. APL: AsinaraPosada Line

From late Cambrian to early Ordovician, the extensional tectonics spread throughout the whole SCM, with the deposition of the Cabitza-San Vito-Solanas Fms (Grabens) and of the Cuili Biringoni Fm (Horsts). Similar deposits also occur in the Kabilies (Boullin et al., 1987) and in Calabria (Minzoni, on going .studies). They correspond to the European "Grès Armoricain". The extend of these deposits indicates a continuity between the SCM and the Variscan Europe until the early Ordovician. Therefore, although there were local signs of incipient rifting, until the early Ordovician the geodynamic regime was governed by slow extensional tectonics, controlled by long-lived normal faults with deposition of shallow water successions and effusion of little or nothing volcanics.

This slow extensional regime drastically changed starting from the middle-late Ordovician. Wrench dynamics caused the sudden development of transpressional and transtesional tectonics. 
The transpressional tectonics played a subordinate role. They developed, in fact, only during the middle Ordovician; ("Sardic Phase"). According to Zwart \& Dornsiepen, 1980, the "Sardic Phase" constituted local event (Fig. 4), linked to the Caledonian orogenesis.

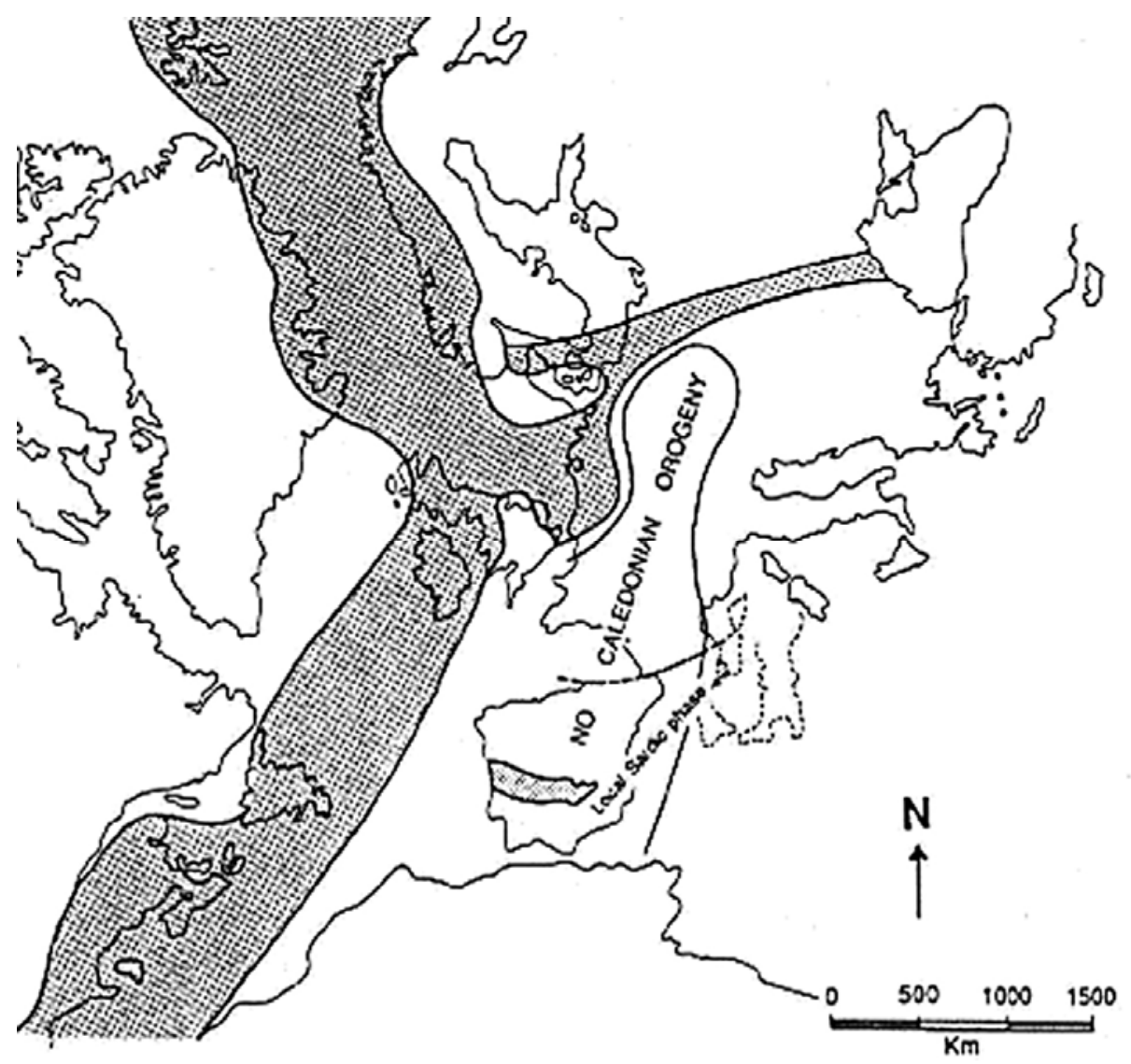

Fig. 4. Area affected by the Caledonian orogenesis and "Sardic Phase"

The transtensional tectonics played the big role. They developed from the middle Ordovician to the Silurian, affecting the zone from central Sardinia to central Corsica. Sinistral strike-slip faults caused the opening of an S-shaped pull apart basin (Fig.5) evolving, in a sequence of closely related stages, from incipient intracontinental rifting to oceanic arm, floored by oceanic crust. The intracontinental rifting stage was characterized, from middle to late Ordovician, by emplacement of the magmatics, ranging from calcalkaline rhyolite to alkaline basalt.

The transtensional tectonics developed with increasing intensity northward, that is toward the internal areas of the basin, characterized by the occurrence of ophiolltes.. The area extended from northern Sardinia to central Corsica may be regarded as the zone affected by maximum in transtension, with opening of the Oceanic arm: Asinara-Posada Ocean, in this article; South Armorican Ocean of Rossi et al., 2009. 
The Variscan orogenesis developed from the late Devonian to the early Carboniferous. The sinistral strike-like master faults, that allowed to the opening of the ocean, now acted as dextral faults thus closing the ocean (Fig.5).

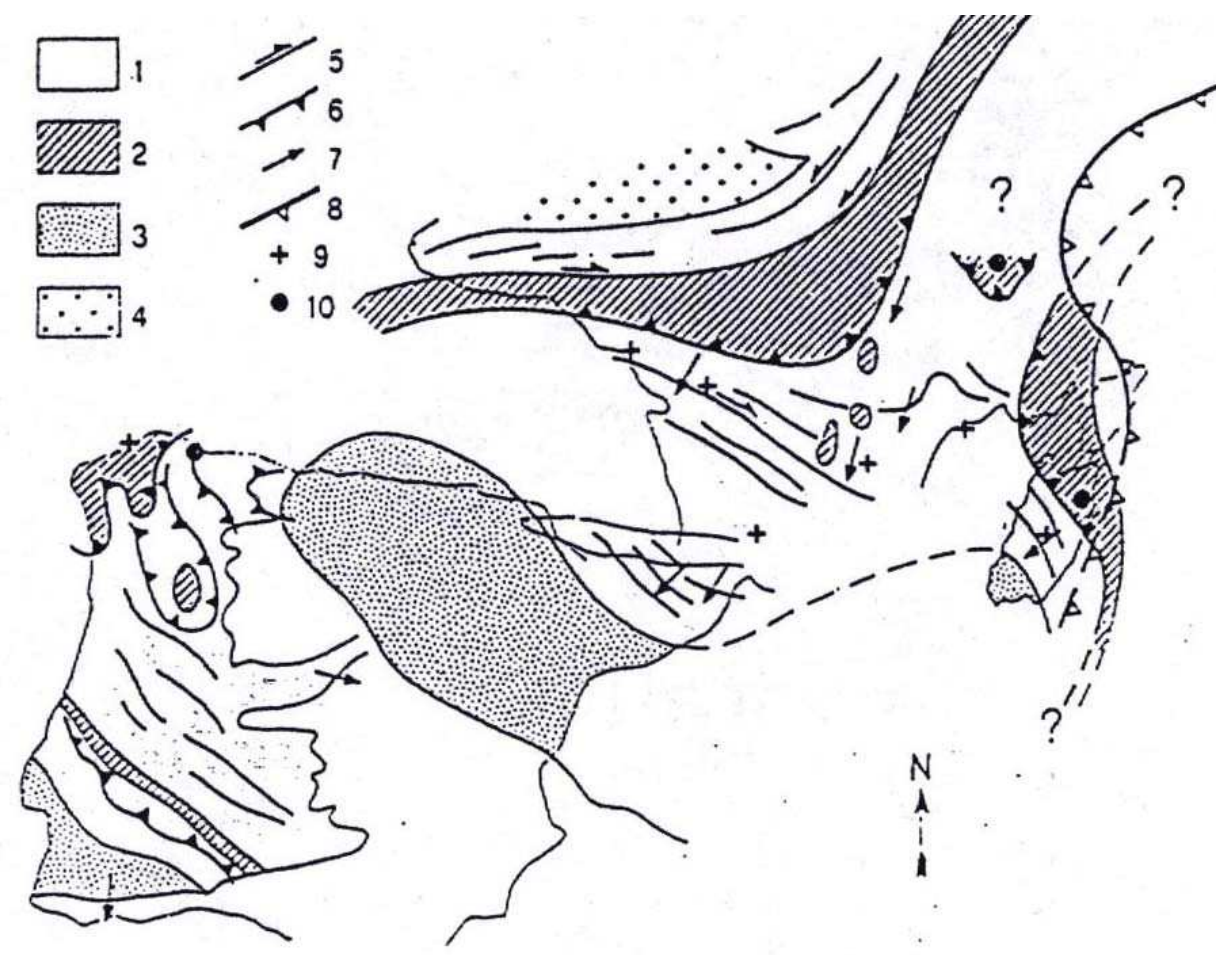

Fig. 5. The Variscan chains in Central-southern Europe

1-Nappe and external zone. 2- Innermost zone, with ophiolitic remnants. 3- Outer foredeep basin. 4-Crystalline basement. 5-Strike-slip faults. 6- Main overthrusts. 7- Tectonic transport. 8- Front of Alpine chain. 9- Early-middle Ordovician bimodal magmatics. 10Ophiolitic suites

Northward subduction of the oceanic lithosphere was followed by the collision of the two passive margins. The northern margin overrode the southern one, (Elter \& Pandeli, 2005; Carosi et al., 2006) with crust-mantle detachment, crustal stacking, oceanic suture along the APL, development of the parauthoctonous nappes in the southern paleomargin (central northern Sardinia), progressive migration of deformation and metamorphism from the suture zone toward the foreland.

The ensialic model proposed by Helbing, 2003 not accounts for the occurrence of ophiolites (Cruciani et al., 2002) and of the magnetic anomaly (Fig. 6) in NE Sardinia, (Cassano et al., 1979; Fais et al., 1994; Cassano et al., 2001). The magnetic anomaly can be related to an important buried mafic body, suggesting a crustal-scale structure, formed by convergence and collision of two passive margins. The ophiolites, exposed at the surface along the APL, may be considered as fragments of oceanic crust, trapped between the two passive margins (Fig.6). 

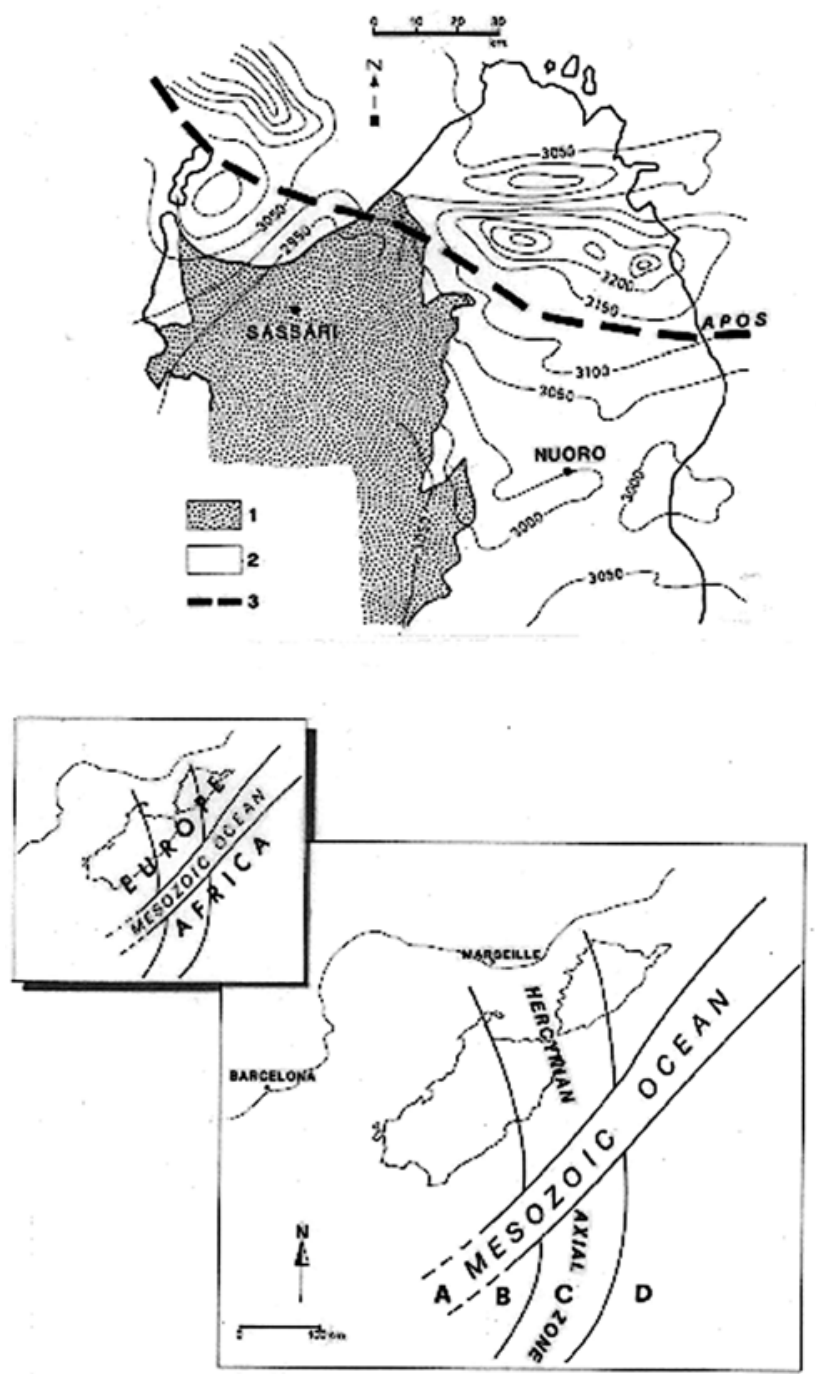

Fig. 6. Aeromagnetic map of northern Sardinia . Contour interval: $50 \mathrm{y}$. 1- Mesozoic and Cenozoic sedimentary cover.

2- Variscan (Hercynian) crystalline rocks. 3-Asinara-Posada Oceanic Suture (APOS).

The Mesozoic Ocean opened East of the Sardinia-Corsica Variscan Massif (Europe) and West of the Variscan Calabria (Africa).

$\mathrm{ABCD}$ represent the palinspasthic restoration of the present Alpine west-verging nappes in Calabria. A- ophiolitic nappes, derived from the Mesozoic Ocean. BCD: crystalline nappes, derived from different tectono-metamorphic zones of the Variscan chain in Calabria. These zones were piled up and transported westward, by the Alpine tectonics. The front of the Alpine chain is shown in Fig.1 and in the Fig. 5 
Oceanic sutures are well documented in several European Variscan segments (Fig 5). Metabasic rocks, with high-pressure relics, occurring along the axial zone of the Variscan chain, have been believed as fragments of oceanic crust, trapped along an oceanic suture, between two passive margins (Burg \& Matte, 1978; Beher et al. 1984; Matte, 1986; Franke, 1989; Pin, 1990; Pin \& Marini, 1993; Matte, 1991; Matte, 2001).

The metabasic rocks often display ocean-floor affinity (Bodinier et al., 1986; Bouchardon et al., 1989; Pin, 1990). The most frequent radiometric datings on the protoliths indicate ages ranging from late Cambrian to early Ordovician (Pin, 1990; Rossi et al., 2009). In some areas, $\mathrm{U} / \mathrm{Pb}$ datings suggested a pre Cambrian age (Peucat et al., 1982; Paquette et al.. 1985). However, more recent studies reinterpreted these data in terms of zircon inheritance through crustal contamination (Paquette, 1987). The ages of the HP-HT metamorphism in the metabasic suites range from Silurian to early Devonian (Peucat et al., 1982; Peucat \& Cogné, 1977; Pin \& Lancèlot, 1982; Paquette 1987; Quadt \& Gebauer, 1988; Matte, 2001), thus indicating subduction of oceanic lithosphere

In the SCM, the Variscan chain was born and shaped along the Paleozoic domains. They were progressively incorporated in the chain, moving from north southward and from late Devonian to early Carboniferous.

The internal zone of the chain was born reutilizing the normal faults which caused the opening, from late Ordovician to Silurian, of the Asinara-Posada ocean. The northern margin overrode, in this way, the southern one with the development of an accretionary wedge.

In the southern margin, the Sarcidano-Sarrabus nappe took place reworking the syn sedimentary normal faults that, from late Cambrian to early Ordovician, allowed to the deposition of the San Vito-Solanas Fms. These faults once inverted, became an enormous sub horizontal thrusting surface which transported the nappe as far as to the north Iglesiente. The underlying Horst was enveloped and fragmented in several small exotic horses (the present Lower external Nappes) in a stacked imbricate antiform.

In the southernmost Sardinia, the whole Paleozoic succession was folded and detached from the pre-Cambrian basement utilizing the syn sedimentary normal faults that allowed to the deposition of the early Cambrian-middle Cambrian formations. This explains the tectonicmetamorphic characteristics of these areas. In fact, deformation and metamorphism increase downward and reach the green schist facies along a sub horizontal shear surface, located between the lowermost Paleozoic deposits and the underlying pre Cambrian basement.

\section{Conclusions}

The transtensional tectonics played during the development of the Variscan geodynamic cycle, a key role causing, from the middle Ordovician to the Silurian, crustal thinning, initiating rifting, emplacement of abundant magmatics, breaking of the continental crust and opening of an oceanic arm (Asinara-Posada Ocean). By the activity of the transtensional tectonics, the true Variscan geodynamic cycle began to develop.

Extensional or transtensional tectonics, reaching their acme during the Ordovician-early Silurian and causing intracontinental rifting and opening of oceanic basins, have been identified in several areas of the European Variscan Realm (Montaigne Noire, Armorican Massif, Pyrenees and Alps). Emplacement of "Bimodal Magmatics" accompanies these tectonics. They are usually related, as in the SCM, to subduction of oceanic lithosphere and 
considered an Andean-type arc. Alternatively, they may be linked (Briand et al., 2002 ) to plume mantle activity prior to the onset of rifting and breaking of the continental lithosphere. Their chemical characteristics may be interpreted in terms of partial melting at different depths of a progressively depleted mantle, during the progressive upwelling within intra continental rifting.

These phenomena developed by several pulsating and space -time evolving episodes. In fact, they migrated from central Europe (with the opening, from late Cambrian to early Ordovician, of the Reich Ocean) to the SCM (with the opening, from the late Ordovician to the early Silurian, of the Asinara- Posada Ocean). It is worthy of note that in the SCM the Variscan orogenesis migrated progressively from north siuthward and from the late Devonian to the early Carboniferous.

This model is consistent with the characteristics of the Variscan chain in the whole Europe. The sutures are characterized by scarcity of oceanic remnants. This may be due to wrench dynamics that led to the opening, by transtensional tectonics, of several pull apart basins. This may also explain the extraordinary complexity of the Variscan orogeny in Europe, its unusual width and its space-time evolution

The SCM and the on going studies in Calabria argue in favor of this model. Their connection with the Variscan Europe is not the result of fortuitous coincidence.

\section{Acknowledgments}

This article took advantage by the collaboration, in computer processing, of my son Christian and by scientific comments of my son Marcello (geologist at Shell Oil Company, Houston, Texas) and of Rebecca (“Becky”), Marcello's wife.

\section{References}

Albani R., Di Milia A., Minzoni N., \& Tongiorgi M. (1985)- Nuovi dati palinologici e considerazioni geologiche sull'età delle Arenarie di Solanas (Cambro- Ordoviciano, Sardegna centrale). Atti Soc, Tosc. Sc, Nat. Mem., 91, 1-20.

Barca S., Cocozza T., Del Rio M. Pillola G.L. \& Pittau Demelia P. ( 1987)- Datation de l'Ordovicien inférieur par Didtyonema flabelliformis dans la partie supérieur de la formation de Cabitza (SW de la Sardaigne, Italy). Coséquences géodinamiques. C.R. Acad. Sc. Paris, 305, 1109-1113.

Barca S., Del Rio M., MinzonI N. \& Pittau P. (1984)- Presenza di Tremadociano ad Acritarchi in unità tettoniche erciniche a sud del Lago di Mulargia (Sardegna centrale). Riv. Paleont. Strat. 89, 315-334. Baudelot S., Doubinger J., Durand-Delga M., \& Vellutini P. (1977)-Caractéristiques et age des cinq cycles Paléozoiques du Nord-Ovest de la Corse. Bull. Soc . Géol. France , 18, 1221- 1228.

Beher M.J., Engel W., Franke W., Giese P.\& Weber K. (1984)- The Variscan Belt in central Europe: main structures, geodynamic implications, open questions. Tectonophisics, $109,15-40$

Bodinier J. L., Giraud A., Dupuy C., Leyreloup A. \& Dostal J. (1986)- Caractérisation géochimique des métabasites associées a la suture hercynienne. Massif Céntral Francaise et chamrouse (Alpes), Bull.Soc. Géol. France, 1, 115-123.

Bosellini A. \& Ogniben G. (1968)- Ricoprimenti ercinici in Sardegna . Ann. Univ. Ferrara, 9,1,1, 11-15. 
Bouchardon J.L., Santallier D., Briand B., Menot R. \& Piboule M.C.(1989)- Eclogites in the French Paleozoic orogen: geodynamic significance. Tectonophisics, 169, 317-322.

Bouillin J. P., Majeste'-Menjoulas C., Baudelot S., Cygan C. \& Fournier-Vinas C.(1987) - Les formations paléozoiques de l'Arc Calabro-Peloritaine dans leur cadre structural. Boll. Soc. Geol. It., 106, 683-698.

Briand B., Bouchardon J.L.,;Capiez P., Piboule M., 2002)-Felsic (A-type)-basic (plume mantle) Early Paleozoic bimodal magmatism in the Maures Massif (Southeastern France).Geologi.cal Magazine, 139; 3, 291-311.

Burg J.P. \& Matte P: (1978)- A cross section through the Frenc Massif and the scope of its Variscan evolution. Z. Dtsch.Geol. Ges., 129, 429-440.

Calvino F. 1961)- Lineamenti strutturali del Sarrabus- Gerrei (Sardegna sud -orientale), Boll. Serv. Geol. It., 81, 489-556.

Cappelli B., Carmignani L., Castorina F., Di Pisa A., Oggiano G. \& Petrini R. (1992)- A Hercynian suture in Sardinia: geological and geochemical evidence. Geodynamica acta, 5, 101-118.

Carmignani L, Barca S., Cappelli B., Di Pisa A., Gattiglio M., Oggiano G., \& Pertusati P.C. (1992)- A tentative geodynamic model for the Variscan basement of Sardinia. IGCP 276, Newsletter 5, 61-82.

Carmignani L., Cocozza T., Minzoni N. \& Pertusati P.C. (1981) -Structural and paleogeographic lineaments of the Variscan cycle in Sardinia. Geologie en Miynbown, 60, 171-181.

Carmignani L., Cocozza T., Minzoni N., Pertusati P.C. \& Ricci C.A (1980)- E' la Corsica il retropaese della catena ercinica in Sardegna? Mem. Soc. Geol. It. , 20, 47-75

Carosi R., Frassi C., Montomoli C. (2006)-Le metamorfiti dell'Anglona e della Gallura sudoccidentale (Sardegna settentrionale, Italia):nuove implicazioni sull'evoluzione post-collisionale della catena sarda. Rend. Soc.Geol. It., 2, Nuova Serie, 108-109

Cassano E., Anelli L. , Cappelli V. \& Latorre P. (2001) - Magnetic and gravity analysis of Italy. In: G.B. Vai and I.P. Martini (eds.), Anatomy of an Orogen: the Apennines and Adjacent Mediterranean Basins, 53-64, Kluver Academic Publishers, Dordrecht/Boston/London

Cassano E., Marcello A., Nannini R., Pretti S., Ranieri G., Salvadori R. \& Salvadori I. (1979)Rilievo aereomagnetico della Sardegna e del mare circostante,. Ente Minerario Sardo, 3/4,7-30.

Cocozza T. (1980) -The Cambrian of Sardinia. Mem.Soc.Geol.It., 20, 163-187.

Cruciani G., Franceschelli M., Marchi M. \& Zucca M. (2002)- Geochemistry of metabasites from NE Sardinia, Italy: nature of the protoliths, magmatic trend and geotectonic setting. Mineralogy and petrology. 74, 25-47.

Dessau G., Duchi G.,Moretti A., \& Oggiano G.,(1982)-Geologia del Valico di Correboi (Sardegna centro-orientale) Boll.Soc. Geol. It. 101, 62-130.

Elter F. \& Pandeli E. (2005)-Structural -metamorphic correlation between three Variscan segments in southern: Maures Massif (France), Corsica(France)-Sardinia(Italy), and northern Appennines (Italy). Journal of the Virtual Explorer, 19, 29-36.

Fais S., Klingele E. E., \& Tocco R. (1994)- Geophisical interpretation of the Gallura magnetic anomaly (north-east Sardinia,Italy). Tectonophisics, 233, (1-2 ), 125-144

Franke W. (1989)- Variscan plate tectonics in central Europe; current ideas and open questions. Tectonophisics, 169, 221-228 
Gandin A., Minzoni N. \& Courjolt-Rade P. (1987)- Shelf- to -basin transition in the Cambrian-lower Ordovician of Sardinia (Italy). Geol. Rund., 76/3, 827-833.

Gandin A. (1987)- Depositional and paleogeographic evolution of Cambrian in S-W Sardinia: IGCP 5, Newsletter 7,151-166.

Ghezzo C., Memmi I. \& Ricci,C.A. (1980) - Un evento granulitico nella Sardegna nordorientale. Mem. Soc. Geol. It. 20, 23-38.

Helbing H. (2003)- No suture in the Sardinian Variscides: a structural, petrological and geochronological analysis. Tübinger Geow. Arbeiten, 68,1-90.

Martini I.P., Tongiorgi M., Oggiano G. \& Cocozza T. (1991)-Ordovician alluvial fan to marine shelf transition in sw Sardinia, western Mediterranean sea: tectonically ("Sardic phase") influenced clastic sedimentation. Sedimentary Geology, 72, 97-115.

Matte P. ( 2001)- The Variscan collage and orogeny (480-290 Ma) and the tectonic definition of the Armorica microplate : a rewiew. Terra Nova , 13, 122-128.

Matte P. (1986) -La chaine Varisique parmi les chaines Palèozoiqes pèri- Atlantiques, Modële d'évolution et position des blocs continentau au permo-carbonifëre, Bull.Soc. France, 8, 9-24.

Matte P.(1991)-Accretionary history and crustal evolution of the Variscan belt in western Europe. Tectonophysics, 196, 309-337.

Memmi I., Barca S., Carmignani L.,Cocozza T., Elter F., Franceschelli M., GAttiglio M., Ghezzo C., Minzoni N., Naud G., Pertusati P.C. \& Ricci C.A. (1982)- Further geochemical data on the pre-Hercynian igneous activities of Sardinia and their geodynamic significance. IGCP 5, Newsletter 5, 87-91.

Minzoni N. ( 1981)- Il pre-Cambriano del Sulcis meridionale (Sardegna). Miner. Petrogr. Acta, 24, 51-56.

Minzoni N. (1975) - La serie delle successioni paleozoiche a sud del Gennargentu . Boll.Soc. Geol. It., 94, 347-392

Minzoni N. (1995)- The Variscan geodynamic cycle in the Sardinian-Corsican Massif, according to the most recent data. J.P. Hogan and M. C. Gilbert eds. Basement tectonics, 12, 155-168.Kluwer Acad. Publ. Netherland.

Paquette J.L (1987)- Comportement des systemes isotopiques U/ Pb et $\mathrm{Sm} / \mathrm{Nd}$ dans le métamorphisme éclogitique. Chaine hercynienne et chaine alpine. Mem. Doc. Cent. Armoricain Etud Struct. Socles. 14, 1-130

Paquette J.L., Peucat J.J., Bernard-Griffiths J. \& Marchand J. (1985)- Evidence for old pre Cambrian relics shown by $\mathrm{u}$-pb zircon dating of eclogites and associated rocks in the Hercynian belt of south Brittany. France. Chem. Geol. 52, 203-216.

Peucat J. \& Cogne' J. (1977) -Geocronology of some blueschists from Ile de Groix (France). Nature 28, 131-132.

Peucat J., Vidal P., Godard G. \& Postaire B. (1982)-Precambrian U-Pb zircon ages of eclogites and garnet pyroxenites from Brittany (France): an old oceanic crust in the $\mathrm{w}$ European Hercynian belt. Earth Plan. Sc. Lett. 60, 70-78.

Pin C. \& Lancélot J. (1982)- U-Pb dating of an early Paleozoic bimodal magmatism in the French Massif Central and its further metamorphic evolution. Contr. Miner. Petrolog. 79, 1-12.

Pin C. (1990) - Variscan oceans: ages, origins and geodynamic implications inferred from geochemical and radiometric data. Tectonophysics , 177, 215-227. 
Pin C.\& Marini F. (1993) - Early Ordovician continental break-up in Variscan Europe: Nd-Sr isotope and trace element evidence from bimodal igneous associoations of the southern Massif Central, France. Lithos 29, 177-196.

Quadt A. \& Gebauer D. (1988) - Sm/Nd, U/Pb and $\mathrm{Rb} / \mathrm{Sr}$ dating of high-pressure ultramafic to felsic rocks from the Moldanubian area of NE Bavaria (FRG) and the Saxonian granulite massif (GDR). Abstract, Conf. Bohemian Massif, (Prague), 71.

Rossi P., Oggiano G. \& Cocherie A.( 2009)- A restored section of the "Southern Variscan realm" across the Sardinia-Corsica microcontinent. C.R. Geosciences, 341, 224-238

Vai G. B. \& Cocozza t. (1986)- Tentative schematic zonation of the Hercynian chain in Italy . Bull. Soc. Geol. France, 2, 95-114

Vai G.B. (2001)- Basement and early (pre-Alpine) history. In: G.B. Vai and I.P. Martini (eds.), Anatomy of an Orogen: the Apennines and Adjacent Mediterranean Basins, 121150, Kluver Academic Publishers, Dordrecht/Boston/London

Zwart H. J. \& Dornsiepen U. F. (1980) - The Variscan and pre-Variscan tectonic evolution of central and western Europe; a tentative model. Sociétè Géologique du Nord, C6, 26 CGI. 227-232. 


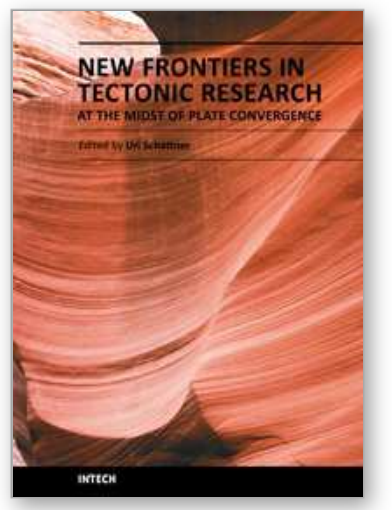

\section{New Frontiers in Tectonic Research - At the Midst of Plate Convergence}

Edited by Dr. Uri Schattner

ISBN 978-953-307-594-5

Hard cover, 352 pages

Publisher InTech

Published online 09, August, 2011

Published in print edition August, 2011

Ocean closure involves a variety of converging tectonic processes that reshape shrinking basins, their adjacent margins and the entire earth underneath. Following continental breakup, margin formation and sediment accumulation, tectonics normally relaxes and the margins become passive for millions of years. However, when final convergence is at the gate, the passive days of any ocean and its margins are over or soon will be. The fate of the Mediterranean and Persian Gulf is seemingly known beforehand, as they are nestled in the midst of Africa-Arabia plate convergence with Eurasia. Over millions of years through the Cenozoic era they progressively shriveled, leaving only a glimpse of the Tethys Ocean. Eventually, the basins will adhere to the Alpine-Himalaya orogen and dissipate. This book focuses on a unique stage in the ocean closure process, when significant convergence already induced major deformations, yet the inter-plate basins and margins still record the geological history.

\section{How to reference}

In order to correctly reference this scholarly work, feel free to copy and paste the following:

Nello Minzoni (2011). Transtensional Tectonics Played a Key Role During the Variscan Cycle in the SardiniaCorsica Massif, New Frontiers in Tectonic Research - At the Midst of Plate Convergence, Dr. Uri Schattner (Ed.), ISBN: 978-953-307-594-5, InTech, Available from: http://www.intechopen.com/books/new-frontiers-intectonic-research-at-the-midst-of-plate-convergence/transtensional-tectonics-played-a-key-role-during-thevariscan-cycle-in-the-sardinia-corsica-massif

\section{INTECH}

open science | open minds

\section{InTech Europe}

University Campus STeP Ri

Slavka Krautzeka 83/A

51000 Rijeka, Croatia

Phone: +385 (51) 770447

Fax: +385 (51) 686166

www.intechopen.com

\section{InTech China}

Unit 405, Office Block, Hotel Equatorial Shanghai

No.65, Yan An Road (West), Shanghai, 200040, China

中国上海市延安西路65号上海国际贵都大饭店办公楼405单元

Phone: +86-21-62489820

Fax: $+86-21-62489821$ 
(C) 2011 The Author(s). Licensee IntechOpen. This chapter is distributed under the terms of the Creative Commons Attribution-NonCommercialShareAlike-3.0 License, which permits use, distribution and reproduction for non-commercial purposes, provided the original is properly cited and derivative works building on this content are distributed under the same license. 